\title{
Hazards of volcanic lakes: analysis of Lakes Quilotoa and Cuicocha, Ecuador
}

\author{
G. Gunkel ${ }^{1}$, C. Beulker ${ }^{1}$, B. Grupe ${ }^{2}$, and F. Viteri ${ }^{3}$ \\ ${ }^{1}$ Berlin University of Technology, Dept. of Water Quality Control, Germany \\ ${ }^{2}$ Berlin University of Technology, Dept. of Water, Environment and Marine Science and Technology (VWS), Germany \\ ${ }^{3}$ Universidad Central, Facultad de Geología Minas, Petroleo and Medio Ambiente, Quito, Ecuador
}

Received: 31 July 2007 - Revised: 4 September 2007 - Accepted: 4 September 2007 - Published: 2 January 2008

\begin{abstract}
Volcanic lakes within calderas should be viewed as high-risk systems, and an intensive lake monitoring must be carried out to evaluate the hazard of potential limnic or phreatic-magmatic eruptions. In Ecuador, two caldera lakes - Lakes Quilotoa and Cuicocha, located in the high Andean region $>3000$ a.s.l. - have been the focus of these investigations. Both volcanoes are geologically young or historically active, and have formed large and deep calderas with lakes of 2 to $3 \mathrm{~km}$ in diameter, and 248 and $148 \mathrm{~m}$ in depth, respectively. In both lakes, visible gas emissions of $\mathrm{CO}_{2}$ occur, and an accumulation of $\mathrm{CO}_{2}$ in the deep water body must be taken into account.

Investigations were carried out to evaluate the hazards of these volcanic lakes, and in Lake Cuicocha intensive monitoring was carried out for the evaluation of possible renewed volcanic activities. At Lake Quilotoa, a limnic eruption and diffuse $\mathrm{CO}_{2}$ degassing at the lake surface are to be expected, while at Lake Cuicocha, an increased risk of a phreaticmagmatic eruption exists.
\end{abstract}

\section{Introduction}

Caldera lakes of active volcanoes must be regarded as highrisk systems that are strongly influenced by volcanic activities such as gas emission, hydrothermal water inflow and rising magma. Interaction of water with hot volcanic bedrock or magma can pose a high risk of a phreatic-magmatic eruption. A total of forty-seven volcanoes with 275 lake eruptions have been recognized to date (Mastin and Witter, 2000). Caldera lakes also have a hazard potential from gas emissions, including the mechanism of limnic eruption - the "Lake Nyos phenomenon" - being well known; a limnic eruption is a spontaneous degassing of a $\mathrm{CO}_{2}$-oversaturated deep water body,

Correspondence to: G. Gunkel

(guenter.gunkel@tu-berlin.de) triggered by upwelling water. In caldera lakes with increased $\mathrm{CO}_{2}$ concentration, diffuse outgassing at the lake surface can occur as well. In addition, the formation of acidic and toxic water due to the emission of such volcanic gases as $\mathrm{HF}, \mathrm{SO}_{2}$, $\mathrm{HCl}$ and gaseous boron must be taken into account, possibly leading to restrictions on water uses (Hansell et al., 2006; Gunkel et al., 2007 ${ }^{1}$ ).

The natural hazards of volcanic lakes have not yet been sufficiently investigated, and knowledge of volcanic lakes is insufficient. Most caldera lakes are still completely unknown, mainly because of a poorly developed limnology and the lack of capacity for volcanic monitoring in many developing countries.

\section{The hazards of volcanic lakes}

For any hazard analysis of volcanic lakes, different types and mechanisms of the activity of both the volcanoes and lakes must be distinguished. Well known is the risk of a phreaticmagmatic eruption, triggered by the percolation of surface or lake water into fractures and fissures, where it comes into contact with the hot bedrock or rising magma (Christenson, 2000). The possibility that the high water pressure of deep lakes may promote percolation of water, and the active role of intensive precipitation in triggering volcanic eruptions, are discussed in Matthews et al. (2002). Little is known about this interaction of lake water percolation and volcanic eruption, but in some cases it could be verified as a possible triggering mechanism for eruptions (Simkin and Siebert, 1994; Mastin and Witter, 2000). Further investigations are necessary to get a better understanding of the water balance and the hydrogeological processes of volcanoes. In general, it must

\footnotetext{
${ }^{1}$ Gunkel, G., Beulker, C., Grupe, B., and Viteri, F.: Hazard analysis of a caldera lake, lake Cuicocha, Ecuador, Bull. Volcanology, submitted, 2007.
}

Published by Copernicus Publications on behalf of the European Geosciences Union. 


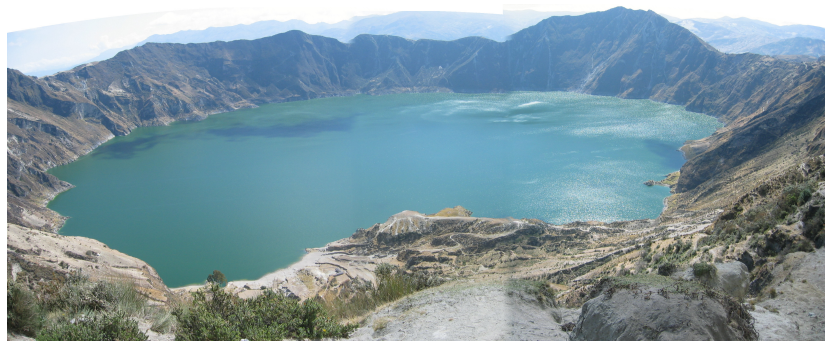

Fig. 1. Caldera Lake Quilotoa, Ecuador.

be pointed out that lakes in volcanic active areas, especially of caldera lakes, have a high risk of eruption.

The emission of $\mathrm{CO}_{2}$ in volcanically active zones is common, and many reports of its lethal impact on animals and humans are known (Hansell et al., 2006). $\mathrm{CO}_{2}$ is lethal at concentrations of $3 \%$ within one hour, and has a narcotic effect, so that people are not aware of, and unable to react to, its effects. $\mathrm{A} \mathrm{CO}_{2}$ gas cloud has a higher density than air, and will spread out at ground level; a high risk of $\mathrm{CO}_{2}$ poisoning exists in caves, small valleys and calderas. The source of $\mathrm{CO}_{2}$ can be either direct emission as volcanic gas, or diffuse emission via the lake surface, due to a higher $\mathrm{CO}_{2}$ concentration in the water, which represents a state of oversaturation in relation to the atmospheric $\mathrm{CO}_{2}$ concentration.

The accumulation of $\mathrm{CO}_{2}$ in volcanic lakes is a well known process since the 1986 disaster of Lake Nyos, Cameroon, which spurred intensive international research to analyse the phenomenon of gaseous eruptions (Le Guern and Sigvaldason, 1989, 1990; Kusakabe, 1994; Martini et al., 1994). Under pressure, large amounts of $\mathrm{CO}_{2}$ are soluble in water - at a depth of $100 \mathrm{~m}$, up to 151 of $\mathrm{CO}_{2}$ gas at atmosphere pressure in 11 of water (Colt, 1984). Consequently, significant $\mathrm{CO}_{2}$ accumulation can be achieved only in deep volcanic lakes, but $\mathrm{CO}_{2}$ accumulation levels in volcanic lakes are strongly influenced by limnological processes, such as thermal or chemical stratification of the water body (inhibition of lake mixing and degassing of $\mathrm{CO}_{2}$ to the atmosphere), such chemical reactions of $\mathrm{CO}_{2}$ as the formation and precipitation of siderite $\left(\mathrm{FeCO}_{3}\right)$ or calcite/aragonite $\left(\mathrm{CaCO}_{3}\right)$, and the bacterial reduction of $\mathrm{CO}_{2}$ to $\mathrm{CH}_{4}$.

Large amounts of accumulated $\mathrm{CO}_{2}$ in a lake can lead to an eruption of the gas, which means water from the depth of the lake moves to the surface due to lake mixing processes, becomes strongly oversaturated and will degas spontaneously; this type of eruption is called a limnic eruption and was proven in Lake Nyos (Cotel, 1999).

The water chemistry of volcanic lakes is determined by volcanic activity, and the emission of volcanic gases such as $\mathrm{CO}, \mathrm{CO}_{2}, \mathrm{HF}, \mathrm{HCl}, \mathrm{SO}_{2}$ and boron compounds, as well as hydrothermal water, can lead to toxic concentrations of some ions, mainly As, B, and $\mathrm{F}$, and to acidic water (introduction of $\mathrm{HCl}$ and $\mathrm{SO}_{2}$ ). Thus, adequate water chemical analyses are necessary prior to any use of water, even of spring water, in volcanically active areas.

Caldera lakes have no regular outflow, and the water level depends strongly on rain inflow. Intensive and long-term water inflow can lead to an increase of the water level and to a lake overflow - by dam failure or uncontrolled flows over the crater rim, which can trigger lahars.

In general, caldera walls have steep slopes, and the deposited volcanic debris, ash or lava flows are relatively young and unconsolidated. Thus, the risk of rock falls and landslides exists, both of which can be triggered by heavy rain or by earthquakes. Landslides and rock falls into the lake can form super-waves and overturn boats and canoes, so that the use of caldera lakes as tourist sites for boating requires adequate monitoring and rescue systems.

\section{Hazard analyses of Lakes Quilotoa and Cuicocha}

\subsection{Volcanic lakes in Ecuador}

In Ecuador, two caldera lakes, Quilotoa and Cuicocha, exist in recently active volcanoes in the high Andean region $>3000$ a.s.l., which have been the focus of a hazard analysis. Both lakes are large and deep -2 to $3 \mathrm{~km}$ in diameter, and $248 \mathrm{~m}$ and $148 \mathrm{~m}$ deep, respectively (Fig. 1).

The Quilotoa volcano had an intensive emission of volcanic ash approx. 800 years ago (Mothes and Hall, 1991, 1998); on some flanks, deposits of $>200 \mathrm{~m}$ are found. A further series of eruptions followed between 1725 and 1797. After the collapse of the dome during the first eruptive period, a crater lake developed, in which increased $\mathrm{CO}_{2}$ concentrations have developed (Aguilera et al., 2000). Some limnic eruptions apparently took place in Lake Quilotoa in 1797 , and today, a high risk of a similar future eruption must be taken into account (Mothes and Hall, 1991, 1998).

Cuicocha is a young volcano adjacent to the inactive Pleistocene Cotacachi volcano. A series of eruptions with intensive ash emission, lahars, and the collapse of the caldera occurred between $2900 \mathrm{BC}$ and $700 \mathrm{AD}$. Over the past few hundred years, a caldera lake has developed, with a maximum depth of $148 \mathrm{~m}$. It has been filled by both rain water and hydrothermal water (Hillebrandt and Hall, 1988; Grupe et al., $2007^{2}$; Gunkel et al., $2007^{1}$ ).

\subsection{Volcanic lake monitoring}

The basis for any limnological evaluation of a volcanic lake is high resolution bathymetry to detect underwater domes and fractures, and determine the slope of the crater rim, along with any possible instability. This can be done by sonar, used

\footnotetext{
${ }^{2}$ Grupe, B., Gunkel, G., Viteri, F., Beulker, C., and von Hillebrandt, C.: The volcano Cuicocha: History and post volcanic activities, In: Recent and Active Volcanism in the Ecuadorian Andes. Special Issue, J. Volcanol. Geoth. Res., submitted, 2007.
} 
was a sonar type Garmin Fishfinder 250C with double frequency (50 and 200 hertz) and a GPS. With a few hundred data per sq. km, good mapping is possible, and can be the basis for a digital elevation model (DEM). The DEM provides a good graphic for visualising the lake's bathymetry and the topography of the watershed, as well as for documenting any changes in the morphologic features.

The composition of sediments in a volcanic lake must be studied to evaluate the interaction with the overlying water, and the type and amount of sediment is of high significance for lake colmation. For lake-sediment studies, an underwater camera and different types of sediment samplers (Eckman Birge, gravity corer) were used in the Lake Cuicocha study.

Knowledge of the water balance is of great significance for determining the water loss of the lake, for example by percolation into fractures and fissures. Volcanic lakes are generally young lakes, with only short time periods for the formation processes of such sediments as carbonate precipitation, so that only small amounts of lake sediment have accumulated. Thus, the colmation of these lakes must be regarded as weak, and of little stability. In volcanic lakes with insufficient colmation, water loss due to percolation into fractures and fissures can occur.

Lake water is strongly influenced by volcanic or geothermal activity, and three phenomena for this effect must be distinguished: 1) the leaching of volcanic deposits in the watershed by rain water; 2) the inflow of hydrothermal water (nearby springs or underwater inflow); and 3) the emission of volcanic gases and their dissolution in the water $\left(\mathrm{CO}_{2}\right.$, $\mathrm{HCl}, \mathrm{HF}, \mathrm{SO}_{2}$, and boron compounds). The goal of water monitoring must be to determine the significance as well as the possible change of activity of these processes. Physical and chemical data for the water enable the determination of thermal or chemical stratification, the turnover rhythm, and the tendency towards volcanic activity (e.g., water heating due to upwelling magma, increased ionic content due to hydrothermal inflow, or acidification due to gas emissions).

In many volcanic areas, gas emissions occur, and are used as an indicator of activity. In volcanic lakes, these gas emissions are visible only in shallow areas, mainly in the littoral zone; in deep lake areas, gas emissions are only detectable by sonar. Good results were obtained in the presented study with a Garmin Fishfinder 250C, double frequency (50 and 200 hertz; Gunkel et al., 2007¹).

\subsection{The hazard of Lake Quilotoa}

Lake Quilotoa, with a salinity of $10.2 \%$, is strongly influenced by hydrothermal water input; present water must be classified as mesohaline. Quilotoa is a weakly stratified lake with no thermocline or chemocline. Rain water input is insignificant, and leads to a decrease in conductivity of only $7 \%$ in the upper water body, the epilimnion, which extends down to $25 \mathrm{~m}$. In the epilimnion, inverse density stratification occurs, due to night cooling with convergence currents,

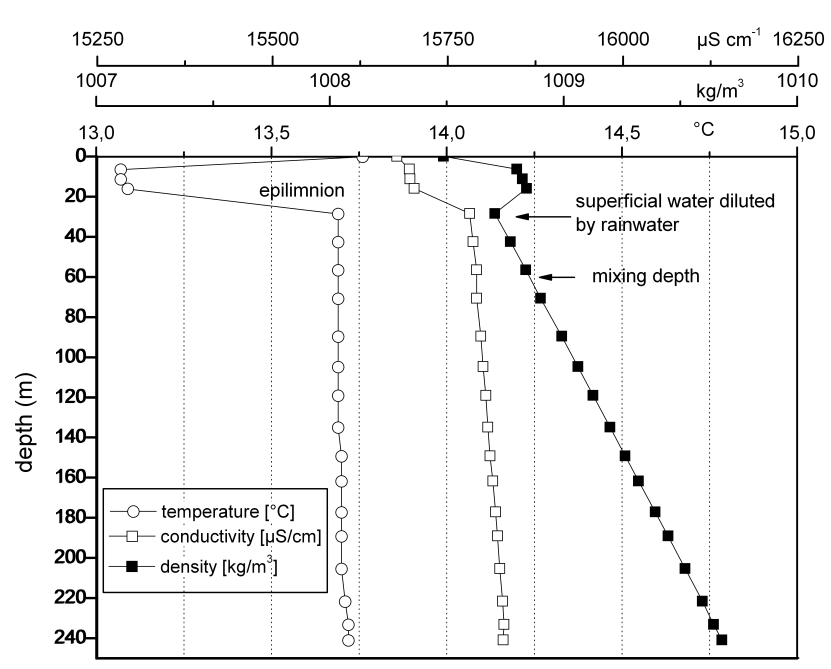

Fig. 2. Temperature, conductivity, and density profiles of Lake Quilotoa measured 11 September 2003.

resulting in a mixed water layer down to $60 \mathrm{~m}$, deeper than the epilimnic zone, so called atelomixis. The deep water body, the hypolimnion, is partly mixed due to upwelling water (rising gas bubbles, hydrothermal water input), but without complete mixing, and the density increases with water depth (Fig. 2). In the hypolimnion, $\mathrm{CO}_{2}$ concentration increases to $0.81 \mathrm{CO}_{2}$ per litre of water.

In Lake Quilotoa, permanent degassing takes place via diffuse gas emissions from the mixed upper water layer, which is about $60 \mathrm{~m}$ deep; $\mathrm{CO}_{2}$ input into this layer occurs by observed hydrothermal water inflow (conductivity = $27900 \mu \mathrm{S} \mathrm{cm}^{-1}$, salinity $=18.7 \%$ o), intensive gas emissions in the littoral lake zone, and by some mixing with the hypolimnic water. Rough estimates of the $\mathrm{CO}_{2}$ input rate suggest that during periods of calm or no wind, toxic $\mathrm{CO}_{2}$ gas clouds can form within the caldera and pose a high risk of asphyxiation.. Even spontaneous degassing is possible, triggered by density currents after a landslide and an upwelling of hypolimnic water. If this water rises to the surface, it will degas rapidly because of its 40 -fold over saturation of $\mathrm{CO}_{2}$ relative to local air pressure. Nonetheless, $\mathrm{CO}_{2}$ accumulation in Quilotoa is much less than in Lake Nyos. Compared with the data gathered by Aguilera in 1993 (Aguilera et al., 2000), lake water in 2003 is characterised by increased water temperature $\left(\Delta T=0.1^{\circ} \mathrm{C}\right)$ and conductivity $(\Delta \mathrm{EC}=600$ $700 \mu \mathrm{S} \mathrm{cm}^{-1}$ ), as well as by a drop in the water level of approx. $20 \mathrm{~m}$ (Fig. 3). It was not possible to undertake any dating of ancient water levels. Unfortunately, further investigations have been hindered by possible violence stemming from civil unrest of the native people living around the lake. 


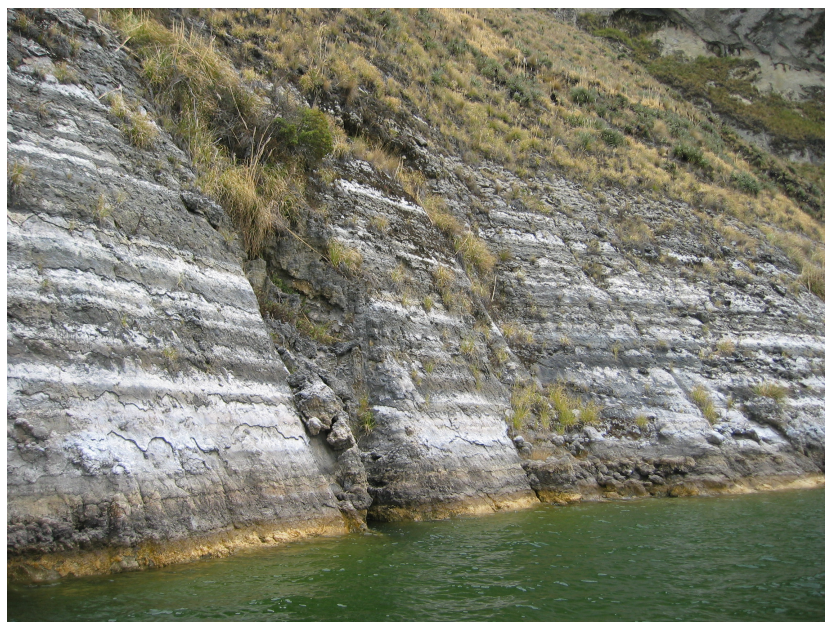

Fig. 3. Progressive decreases in water level at Lake Quilotoa, as recorded by calcium carbonate precipitations.

\subsection{The hazard of Lake Cuicocha}

Lake Cuicocha has no visible continuous inflow and no direct outflow, but short-lived occasional heavy rainfalls and the input of surface water from the catchment area feed the lake. Lake Cuicocha also has hydrothermal water inflow, but ionic concentration is still in the range of natural lake water $\left(700 \mu \mathrm{S} \mathrm{cm}^{-1}\right)$ - this is caused by hydrothermal water inflow of relatively low temperature and conductivity $\left(23.5^{\circ} \mathrm{C}\right.$, $\left.2880 \mu \mathrm{S} \mathrm{cm}^{-1}\right)$. Cuicocha is a typical monomictic lake with one overturn during the windy dry period. During the course of this overturn, degassing occurs, but no high accumulation level of $\mathrm{CO}_{2}$ is observed ( 0.031 of $\mathrm{CO}_{2} / 1$ water). In Lake Cuicocha, regular gas emissions with high intensity were detected at $78 \mathrm{~m}$ depth; this gas emission area covers a $500 \times 600 \mathrm{~m}$ zone in the western bay of the lake. Additionally, gas emissions happen at three other places, at water depths $<10 \mathrm{~m}$. The gas, mainly $\mathrm{CO}_{2}$ and $\mathrm{N}_{2}$, is of volcanic origin, due to the occurrence of $\mathrm{CO}$ and the accumulation of boron in the lake. There is no risk of a limnic eruption or a $\mathrm{CO}_{2}$ gas cloud formation due to diffuse degassing.

After an earthquake in 1987, a rapid water level drop was observed for several weeks, probably caused by damage to the lake's colmation, totalling approx. $6 \mathrm{~m}$; recently the water level has been dropping by about $30 \mathrm{~cm}$ per year. This is evident along the shoreline of the lake, where dried algae and carbonate precipitations record former lake water levels. Thus, a significant amount of the lake's water, approx. $3000 \mathrm{~m}^{3} /$ day, is lost by percolation into fractures and fissures of the bedrock. This water level decrease cannot be explained by reduced rainfall due to climate change, because similar declines in level have not taken place at the nearby lakes of Laguna Mojanda and Lago San Pablo.

Investigations of the sediments using an underwater camera and sediment corer were carried out, but sediment sam-

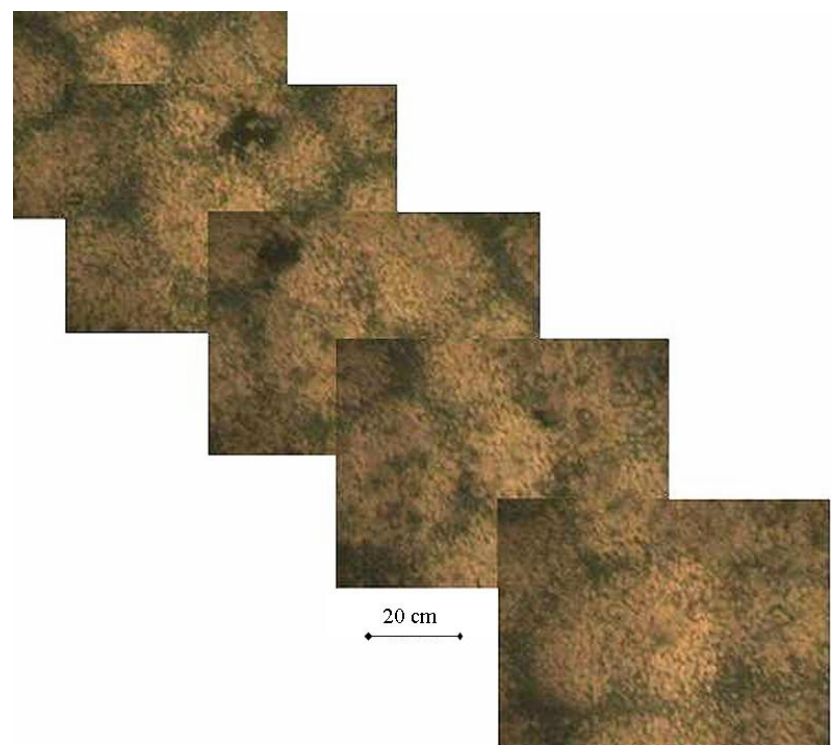

Fig. 4. Sediments of Lake Cuicocha at $78 \mathrm{~m}$ depth showing pores between the rocks and the overlying fine sediment layer.

pling was not very successful in Lake Cuicocha due to sediment loss during raising of the equipment. The Cuicocha lake floor consists of rocks, mainly with a diameter of $20 \mathrm{~cm}$, covered by a thin layer of fine anoxic sediments with an oxic surface layer. Cuicocha has calcium-poor sediment, because of a negative calcium carbonate saturation index, which means that calcium dissolution occurs. On the lake floor, pores are recognisable, probably opened by rising gas bubbles and hydrothermal water (Fig. 4). Consequently, the colmation of the lake has been damaged, and the percolation of lake water into fractures under the caldera can occur.

Collectively, the thin sediment layer, the inhomogeneity of the lake floor, and the drop in water level are consistent with the inferred percolation of water into fractures and fissures. Such percolation of lake water leads to increased likelihood of a phreato-magmatic eruption; recently, the effect of water percolation as a trigger mechanism for volcanic eruptions has been discussed intensively (e.g., Mastin and Witter, 2000; Matthews et al., 2002; Barclay et al., 2006). Thus, investigations of lake colmation and regular monitoring of lake temperature, gas emissions, and increasing hydrothermal activity must be carried out, together with volcano-monitoring studies of the Cuicocha caldera.

Lake heating $\left(\Delta T=0.1^{\circ} \mathrm{C}\right.$ year) and the occurrence of new underwater inflow of hydrothermal water, registered by divers, indicate increasing activity of the volcano.

\section{Concluding remarks}

Lakes in volcanic active areas must be the focus of hazard analyses; to date, many of them are not been sufficiently 
investigated. However, one challenge is that any change in lake activity is only detectable via special limnological monitoring techniques, such as using a lake profiler, under water camera, sonar and, for shallow lakes, SCUBA divers. The feasibility of such lake monitoring has been demonstrated at Lakes Quilotoa and Cuicocha, revealing increased hazards at both lakes, but involving different mechanisms.

Lake Quilotoa shows an atypical water mixture called atelomixis, known only in tropical high mountain lakes (Imberger, 1985; Gunkel and Casallas, 2002); as a consequence of this frequent partial mixing, degassing of $\mathrm{CO}_{2}$ by diffuse emission can occur, and a lethal gas cloud could develop during periods of calm or no wind in the caldera.

Lake Cuicocha is an example of a lake with insufficient colmation - a common condition for young volcanic lakes. The amount of in situ formed sediments, mainly carbonates and organic material, is small, and a re-opening of the colmation layer can be caused by earthquakes or rock slides. Percolation of lake water into fractures and fissures could lead to contact of that water with hot bedrock or rising magma, thereby increasing the risk of a phreatic magmatic eruption.

Edited by: P. Fabian

Reviewed by: R. Tilling and an anonymous referee

\section{References}

Aguilera, E., Chiodini, G., Cioni, R., Guidi, M., Marini, L., and Raco, B.: Water chemistry of lake Quilotoa (Ecuador) and assessment of natural hazards, J. Volcanol. Geoth. Res., 97, 271$285,2000$.

Barclay, J., Johnstone, J. E., and Matthews, A. J.: Meteorological monitoring of an active volcano: Implications for eruption prediction, J. Volcanol. Geoth. Res., 150, 339-358, 2006.

Christenson, B. W.: Convection and stratification in Ruapehu Crater Lake, New Zealand: Implicaations for Lake Nyos-type gas release eruptions, Geochem. J., 28, 185-197, 1994.

Colt, J.: Computation of dissolved gas concentrations in water as functions of temperature, salinity, and pressure, American Fisheries Society, Special Publication 14, 155 pp., 1984.
Cotel, A. J.: A trigger mechanism for the Lake Nyos disaster, J. Volcanol. Geoth. Res., 88, 343-347, 1999.

Gunkel, G. and Casallas, J.: Limnology of an equatorial high mountain lake - Lago San Pablo, Ecuador: The significance of deep diurnal mixing for lake productivity, Limnologica, 32, 33-43, 2002.

Hansell, A. L., Horwell, C. J., and Oppenheimer, C.: The health hazards of volcanoes and geothermal areas, Occup. Environ. Med. 63, 149-156, 2006.

Imberger, J.: The diurnal mixed layer, Limnol. Oceanogr., 30, 737770, 1985.

Le Guern, F. and Sigvaldason, G. E.: The Lake Nyos event and natural $\mathrm{CO}_{2}$ degasing I, Special issues, J. Volcanol. Geoth. Res., 39, 2-3, 1989.

Le Guern, F. and Sigvaldason, G. E.: The Lake Nyos event and natural $\mathrm{CO}_{2}$ degasing II, Special issues, J. Volcanol. Geoth. Res., 42, 4, 1990.

Martini, M., Giannini, L., Prati, F., Tassi, F., Capaccioni, B., and Ioizzelli P.: Chemical characters of crater lakes in the Azores and Italy: the anomaly of Lake Albano, Geochem. J., 28, 173-184, 1994.

Mastin, L. G. and Witter, J. B.: The hazards of eruptions through lakes and seawater, J. Volcanol. Geoth. Res., 97, 195-214, 2000.

Matthews, A. J., Barclay, J., Carn, S., Thompson, G., and Alexander, J.: Rainfall-induced volcanic activity on Montserrat, Geophys. Res. Lett., 29, 13, 22-1-22-4, 2002.

Mothes, P. and Hall, M. L.: El paisaje interandino y su formación por eventos volcanicos de gran magnitude, Estudios de Geografía 4, 19-38, 1991.

Mothes, P. and Hall, M. L.: Quilotoa's 800 y BP Ash: A valuable stratigraphic marker unit for the integration period, in: Actividad Volcánica y pueblos precolombinos en el Ecuador, edited by: Mothes, P., Abya-Yala, Quito, 111-138, 1998.

Simkin, T. and Siebert, L.: Volcanoes of the world, Geoscience Press, Tuscon, AZ, 349 pp., 1994.

von Hillebrandt, C. and Hall, M. L.: Mapa de los Peligros Volcánoicos Potenciales Asociados con el Volcán Cuicocha, Esc. 1:50.000, Escuela Politécnica Nacional, Quito, Instituto Geográfico Militar, 1988. 